\title{
Wpływ pandemii Koronawirusa (COVID-19) na jakość życia rodziny i dziecka
}

\author{
Impact of the Coronavirus (COVID-19) pandemic on the quality of life \\ of the family and the child
}

\author{
KATARZYNA MARIANNA PŁOSZAJ ${ }^{1}$, DOROTA KOCHMAN ${ }^{2}$ \\ 1 Wojewódzki Szpital Specjalistyczny we Włocławku, Oddział Ortopedii \\ 2 Państwowa Uczelnia Zawodowa we Włocławku, Instytut Nauk o Zdrowiu
}

\section{Streszczenie}

Wstęp. W marcu 2020 roku cały świat rozpoczął walkę z nieznanym dotąd wrogiem - Koronawirusem SARS-CoV-2 zwanym także COVID-19. Sytuacja pandemii znacznie wpłynęła na funkcjonowanie rodziny.

Cel. Celem pracy jest analiza jakości życia dziecka i rodziny w dobie zaostrzeń związanych z pandemią Koronawirusa (COVID-19).

Materiał i metody. Za pomocą metody sondażu diagnostycznego, przy użyciu ankiet własnego autorstwa badano jakość życia całej rodziny i dzieci w trakcie hospitalizacji w czasach pandemii. Procedurę badawczą przygotowano również na podstawie przeprowadzenia oryginalnej wersji kwestionariusza KIDSCREEN 27. Badanie przeprowadzono wśród 200 osób. Badani to dzieci i młodzież (100 osób) byli pacjentami Oddziału Dziecięcego Obserwacyjnego Specjalistycznego Szpitala Wojewódzkiego we Włocławku oraz grupa rodziców tych dzieci licząca 100 osób.

Wyniki. Za pomocą wymienionych powyżej narzędzi badawczych wykazano, że pandemia COVID-19 w badanej grupie wpływa negatywnie na każdy aspekt życia całej rodziny. Dochodzi do zaburzeń zdrowia fizycznego, psychicznego i relacji społecznych samego dziecka, a konsekwencji także jego najbliższych.

Wnioski. Jakość życia w rodzinie w dobie pandemii nabiera całkiem innego wymiaru. W wyniku restrykcji konieczne jest przeorganizowane życia w każdej sferze. Prowadzi to do szeregu negatywnych konsekwencji, a mianowicie pogorszeniu ulega zdrowie fizyczne nie tylko dziecka, ale też pozostałych 
członków rodziny, zdrowie psychiczne całej rodziny, a także dochodzi do zaburzenia umiejętności nawiązywania prawidłowych relacji społecznych.

Słowa kluczowe: pandemia, covid-19, jakość życia, dziecko, rodzina

\section{Summary}

Admission. In March 2020, the whole world began to fight a previously unknown enemy - the SARS-CoV-2 coronavirus, also known as COVID-19. The pandemic had a significant impact on functioning of the family.

Aim. The aim of the study is to analyze the quality of life of a child and family in the time of exacerbations related to the Coronavirus (COVID-19) pandemic.

Material and methods. The quality of life of the entire family and children during hospitalization during the pandemic was investigated using the diagnostic survey method, with the use of self-authored questionnaires. The research procedure was also prepared on the basis of the original version of the KIDSCREEN 27 questionnaire. The research was conducted among 200 people. The examined children and adolescents (100 people) were patients of the Children's Observation Department of the Specialist Provincial Hospital. in Włocławek and a group of 100 parents of these children.

Results. Using the above-mentioned research tools, it has been shown that the COVID-19 pandemic in the study group negatively affects every aspect of the life of the entire family. The child's physical and mental health and social relations are disturbed, as well as their relatives.

Conclusions. The quality of life in family during a pandemic takes on a completely different dimension. As a result of the restrictions, it is necessary to reorganize life in every sphere. This leads to a number of negative consequences, namely the physical health of not only the child deteriorates, but also other family members, the mental health of the whole family, and the ability to establish proper social relationships is impaired.

Keywords: pandemic, covid-19, quality of life, child, family 


\section{Wstęp}

Choroby zakaźne przenoszone z człowieka na człowieka nie są niczym niezwykłym i towarzyszą ludzkości od wieków. Ich pojawienie się wywoływało zawsze określone reakcje i zachowania całych zbiorowości, co zmieniało dotychczasowe zwyczaje i wprowadzało różne, mniej lub bardziej skuteczne sposoby walki ze konsekwencjami zarazy.

Od marca 2020 roku cały świat zatrzymał się w miejscu i rozpoczął walkę z nieznanym dotąd wrogiem - Koronawirusem SARS-CoV-2 zwanym także COVID-19. Początkowo społeczeństwo polskie sceptycznie traktowało doniesienia z prasy czy rządowe zalecenia. Niektórzy do tej pory podważają istnienie wirusa i próbują bojkotować wiedzę badaczy. Sytuacja stała się na tyle poważna, że szpitale zakaźne w zastraszającym tempie zaczęły się zapełniać, a prasa donosiła o kolejnych liczbach osób zarażonych i zgonach. Piętno pandemii odcisnęło się dramatycznie w środowisku ochrony zdrowia oraz na krajowej gospodarce [1].

W samym środku zamieszania związanego z natłokiem doniesień oraz wszelakich obostrzeń pojawia się rodzina. To najważniejsza i najbliższa naszemu sercu grupa społeczna, w której żyjemy i dzielimy się na co dzień troskami, problemami oraz radościami naszego życia. Sytuacja pandemii COVID-19 znacznie zmieniła funkcjonowanie rodziny. Rodzina zaczęła żyć niejako we własnym kręgu, stosując się do koniecznej izolacji od przyjaciół, znajomych i dalszych członków rodziny. Dzieci także pozostały w domu, z klasą i nauczycielami kontaktując się online. Zmiany $w$ funkcjonowaniu życia codziennego zmusiły rodziny do znacznej reorganizacji [2].

Ogromnym wyzwaniem zarówno dla osób dorosłych jak i dla dzieci, stały się wizyty $\mathrm{w}$ przychodniach czy pobyty w szpitalu. W dobie pandemii COVID-19 w szpitalach obowiązuje zaostrzony reżim sanitarny i zakaz odwiedzin. Oznacza to, że kontakt hospitalizowanego pacjenta z najbliższymi jest ograniczony wyłącznie do rozmowy telefonicznej. Hospitalizacja, zwłaszcza dzieci poniosła za sobą jeszcze więcej leków i niepokoju niż w czasach przed pandemią. Funkcjonowanie rodziny i dziecka zostało naznaczone wieloma zmianami [3]. 


\section{Cel}

Celem niniejszej pracy jest analiza jakości życia rodziny i dziecka w dobie pandemi.

\section{Materiał i metody}

Badanie przeprowadzono wśród 200 osób, w tym 100 dzieci w wieku od 8 do 18 lat, a także 100 rodziców dzieci. Badani byli pacjentami Oddziału Dziecięcego Obserwacyjnego Specjalistycznego Szpitala Wojewódzkiego we Włocławku.

Badania przeprowadzono za pomocą ankiet własnego autorstwa, które dotyczyły odczuć związanych z pobytem w szpitalu w dobie pandemii. Następnie dodatkowo za pomocą kwestionariuszy KIDSCREEN 27 dzieci i rodzice udzielili odpowiedzi na zadane pytania, dzięki którym można ocenić jakość życia przed nastaniem pandemii w Polsce, związaną ze zdrowiem dzieci i dokonać oceny zadowolenia z życia.

Wśród rodziców zdecydowanie liczniejszą grupę stanowiły kobiety i zarazem matki badanych dzieci - 78\%. Znaczna grupa przebadanych rodziców bo aż $90 \%$ była w przedziale wiekowym miedzy 26 . a 45 . rokiem życia. Większość badanych stanowili mieszkańcy wsi - 62 osoby. Najwięcej badanych posiadało wykształcenie średnie ogólnokształcące - 51 osób, wykształcenie wyższe (26,0\%), zawodowe $(22,0 \%)$ najmniej podstawowe - 1 osoba $(1,0 \%)$.

Wśród dzieci znaczną grupę stanowiły dziewczęta - 54 osoby (54,0\%). Najliczniejszą grupę badanych stanowiły dzieci w wieku 12 lat (21,0\%), kolejną liczną grupę stanowiły dzieci w wieku 13 lat $(15,0 \%)$, najmniej ankietowanych było w grupie młodzieży - 1 osoba w wieku 18 lat $(1,0 \%)$. Do zbadania zależności statystycznej pomiędzy analizowanymi cechami użyto testu chi kwadrat. 


\section{Wyniki}

\section{Analiza kwestionariusza dla rodziców}

Znaczna większość rodziców była zaniepokojona pobytem dziecka w szpitalu - 77 osób $(77,0 \%)$ a 83,0\% ankietowanych odczuwało strach przed możliwością zakażenia COVID-19. Ponad połowa ankietowanych - 60 osób (60,0\%) nie pozostała z dzieckiem w szpitalu. Odpowiadając na pytanie dotyczące rzetelności otrzymywanych informacji, jasnych i spójnych na temat zdrowia dziecka, większość rodziców - 71 osób $(71,0 \%)$ zaznaczyła odpowiedź tak. Większość rodziców na pytanie dotyczące dostępności do środków ochrony osobistej w szpitalu- 65 osób $(65,0 \%)$ uznała, że mają taki dostęp, z kolei grupa 31 osób $(31,0 \%)$ nie widziała, że taka możliwość istnieje.

Dla większości osób badanych edukacja rodziców przez personel z zakresu podstawowych zasad higieny, które mają na celu zabezpieczenie przed zakażeniem COVID-19 - 68 osób (68,0\%) była wystarczająca, tylko mała grupa ankietowanych - 10 osób $(10,0 \%)$ w swoim odczuciu nie została wyedukowana.

Odpowiadając na pytanie dotyczące dostępności odpowiednich warunków lokalowych - ponad połowa - 51 osób $(51,0 \%)$ uznała, że szpital nie zapewnia takiej dostępności, tylko 30 osób $(30,0 \%)$ w swoim odczuciu uważała, że przeciwnie.

Badanie wykazało, że duża grupa rodziców - 65 osób (65,0\%), wyraziła chęć pozostawienia dziecka w szpitalu tylko pod opieką pracowników oddziału. Mała grupa 28 osób (28,0\%) nie zgadzała się na taką ewentualność. Ogromna grupa ankietowanych - 78 osób $(78,0 \%)$ uważa, że ich pociechy czują samotność związaną z pobytem w szpitalu, tylko 15 osób $(15,0 \%)$ ma odmienne zdanie. Znacząca część rodziców 84 osoby $(84,0 \%)$ obserwuje tęsknotę swoich pociech za środowiskiem rodzinnym. Mała grupa 12 osób (12,0\%) nie widzi takich uczuć u swoich dzieci. Ponad połowa ankietowanych 59 osób (59,0\%) uznała, że ich dzieci czują się bezpiecznie w trakcie hospitalizacji. Tylko 16 osób (16,0\%) miało zadanie odmienne. Ogromna liczba ankietowanych 90 osób (90,0\%) uważa, że pandemia COVID-19 ma wpływ na relacje rodzinne. 


\section{Analiza kwestionariusza dla dzieci i młodzieży}

Duża grupa ankietowanych 63 osoby $(63,0 \%)$ wykazała, iż odczuwa niepokój związany z pobytem w szpitalu, a 67 osób $(67,0 \%)$ odczuwa strach przed możliwością zakażenia COVID-19. Ponad połowa dzieci - 54 osoby $(54,0 \%)$ pozostaje na noc w szpitalu bez towarzystwa rodziców. Znaczna liczba ankietowanych 79 osób $(79,0 \%)$ uznaje, że zostały im przedstawione zasady panujące na danym oddziale, a duża grupa dzieci - 61 osób $(61,0 \%)$ uważa, że rodzice mają dostęp do informacji o ich stanie zdrowia. Tylko 3 osoby $(3,0 \%)$ ma przeciwną opinię. Ponad połowa badanych - 52 osoby (52,0\%) uznaje, że pracownicy oddziału przekazują informacje jasno i spójnie.

Badania wykazały, że 42 osoby (42,0\%) uznały dostępność do podstawowych środków ochrony osobistej, ale 40 badanych $(40,0 \%)$ przyznaje, że nie ma wiedzy na ten temat.

Duża grupa badanych (70\%) uznaje, że została wyedukowana przez personel z zakresu podstawowych zasad higieny, celem uchronienia przez zakażeniem COVID-19.

Badania wykazały, że 69 osób $(69,0 \%)$ uważa, że szpital nie zapewnia dostatecznych warunków lokalowych. Tylko 7 osób $(7,0 \%)$ podaje, że mają odpowiedni dostęp.

W badaniu chęć pozostania w szpitalu jedynie pod opieką personelu zadeklarowało 54 osoby $(54,0 \%)$, z kolei 40 dzieci $(40,0 \%)$ nie chce pozostać bez opieki.

Ogromna liczba badanych 88 osób (88,0\%) uznaje, że jest samotna podczas hospitalizacji, a duża grupa dzieci - 91 osób (91,0\%) uważa, że tęskni za domem podczas pobytu w szpitalu. Według ankietowanych 45 osób (45,0\%) podaje, że czuje się bezpiecznie w trakcie hospitalizacji, 40 osób (40,0\%) nie potrafi wyrazić konkretnej opinii na ten temat, a ostatnia grupa 15 osób (15,0\%) nie czuje się bezpiecznie w szpitalu.

Znacząca grupa - 88 osób (88,0\%) uznaje, że pandemia COVID-19 wypływa na relacje w rodzinie, zaś mała ankietowanych - 12 osób $(12,0 \%)$ nie jest w stanie wypowiedzieć się jednoznaczne na omawiany temat. 


\section{Analiza kwestionariusza KIDSCREEN-27}

Kwestionariusz KIDSCREEN 27 służy do ogólnej oceny jakości życia wśród dzieci i młodzieży w wieku 8-18 lat. W omawianym przypadku narzędzie badawcze skierowane było do grupy rodziców oraz dzieci młodzieży i odnosiło się do oceny jakości życia czasów przed rozpoczęciem pandemii COVID-19.

Tabela 1. Interpretacja wyników grupy rodziców.

\begin{tabular}{|l|c|c|c|c|c|}
\hline RODZICE & N & Minimum & Maksimum & Średnia & SD \\
\hline $\begin{array}{l}\text { zdrowie } \\
\text { fizyczne }\end{array}$ & 100 & 25,00 & 95,00 & 64,7000 & 14,61319 \\
\hline $\begin{array}{l}\text { samopoczucie } \\
\text { psychiczne }\end{array}$ & 100 & 29,00 & 68,00 & 49,9500 & 7,12426 \\
\hline $\begin{array}{l}\text { niezależność } \\
\text { i relacje } \\
\text { z rodzicami }\end{array}$ & 100 & 32,00 & 96,00 & 63,9500 & 14,94527 \\
\hline $\begin{array}{l}\text { rówieśnicy } \\
\text { i wsparcie } \\
\text { społeczne }\end{array}$ & 100 & 23,10 & 50,00 & 41,1850 & 7,52880 \\
\hline $\begin{array}{l}\text { środowisko } \\
\text { szkolne }\end{array}$ & 100 & 19,20 & 61,50 & 45,3990 & 9,65951 \\
\hline
\end{tabular}

n - liczba obserwacji, SD - odchylenie standardowe

Z obserwacji przeprowadzonych badań wynika, iż ankietowani w czasie przed rozpoczęciem pandemii COVID-19 najlepiej oceniali zdrowie fizyczne swoich dzieci $(64,7)$ oraz niezależność i relacje z rodzicami $(63,95)$. Najniżej natomiast wsparcie społeczne i rówieśników $(41,18)$ a także środowisko szkolne $(41,18)$ i samopoczucie psychiczne $(49,95)$. 
Tabela 2. Interpretacja wyników grupy dzieci i młodzieży.

\begin{tabular}{|l|c|c|c|c|c|}
\hline $\begin{array}{l}\text { DZIECI } \\
\text { I MŁODZIEŻ }\end{array}$ & N & Minimum & Maksimum & Średnia & SD \\
\hline $\begin{array}{l}\text { zdrowie } \\
\text { fizyczne }\end{array}$ & 100 & 30,00 & 90,00 & 63,6500 & 12,74963 \\
\hline $\begin{array}{l}\text { samopoczucie } \\
\text { psychiczne }\end{array}$ & 100 & 32,00 & 64,00 & 51,1100 & 6,96585 \\
\hline $\begin{array}{l}\text { niezależność } \\
\text { i relacje } \\
\text { z rodzicami }\end{array}$ & 100 & 33,00 & 96,00 & 60,6500 & 15,21454 \\
\hline $\begin{array}{l}\text { rówieśnicy } \\
\text { i wsparcie } \\
\text { społeczne }\end{array}$ & 100 & 31,00 & 81,00 & 61,8400 & 14,37220 \\
\hline $\begin{array}{l}\text { środowisko } \\
\text { szkolne }\end{array}$ & 100 & 44,00 & 100,00 & 70,1100 & 18,07219 \\
\hline
\end{tabular}

n - liczba obserwacji, SD - odchylenie standardowe

Na podstawie wyników kwestionariusza KIDSCREEN 27 dzieci i młodzież odnosząc się do czasów sprzed rozpoczęcia pandemii COVID-19 najwyżej oceniają środowisko szkolne $(70,11)$, zdrowie fizyczne $(63,65)$, rówieśnicy i wsparcie $(61,84)$ oraz niezależność i relacje z rodzicami $(60,65)$ najniżej natomiast samopoczucie psychiczne $(51,11)$. 
Tabela 3. Porównanie wyników grupy rodziców i grupy dzieci i młodzieży.

\begin{tabular}{|c|c|c|c|c|c|c|c|}
\hline \multicolumn{2}{|c|}{ KIDSCREEN 27} & Średnia & $\mathbf{N}$ & SD & Kore- & $\mathbf{t}$ & $\mathbf{p}$ \\
\hline rodzice & $\begin{array}{l}\text { zdrowie } \\
\text { fizyczne }\end{array}$ & 64,7000 & 100 & 14,61319 & \multirow{2}{*}{0,24177} & \multirow{2}{*}{0,62087} & \multirow{2}{*}{0,53611} \\
\hline $\begin{array}{l}\text { dzieci } \\
\text { i młodzież }\end{array}$ & $\begin{array}{l}\text { zdrowie } \\
\text { fizyczne }\end{array}$ & 63,6500 & 100 & 12,74963 & & & \\
\hline rodzice & $\begin{array}{l}\text { samopoczucie } \\
\text { psychiczne }\end{array}$ & 49,9500 & 100 & 7,12426 & \multirow{2}{*}{0,23011} & \multirow{2}{*}{$-1,32679$} & \multirow{2}{*}{0,18763} \\
\hline $\begin{array}{l}\text { dzieci } \\
\text { i młodzież }\end{array}$ & $\begin{array}{l}\text { samopoczucie } \\
\text { psychiczne }\end{array}$ & 51,1100 & 100 & 6,96585 & & & \\
\hline rodzice & $\begin{array}{l}\text { niezależność } \\
\text { i relacje } \\
\text { z rodzicami }\end{array}$ & 63,9500 & 100 & 14,94527 & \multirow{2}{*}{0,25495} & \multirow{2}{*}{1,79258} & \multirow{2}{*}{0,07609} \\
\hline $\begin{array}{l}\text { dzieci } \\
\text { i młodzież }\end{array}$ & $\begin{array}{l}\text { niezależność } \\
\text { i relacje } \\
\text { z rodzicami }\end{array}$ & 60,6500 & 100 & 15,21454 & & & \\
\hline rodzice & $\begin{array}{l}\text { rówieśnicy } \\
\text { i wsparcie } \\
\text { społeczne }\end{array}$ & 41,1850 & 100 & 7,52880 & \multirow{2}{*}{0,04701} & \multirow{2}{*}{$-12,98389$} & \multirow{2}{*}{0,00000} \\
\hline $\begin{array}{l}\text { dzieci } \\
\text { i młodzież }\end{array}$ & $\begin{array}{l}\text { rówieśnicy } \\
\text { i wsparcie } \\
\text { społeczne }\end{array}$ & 61,8400 & 100 & 14,37220 & & & \\
\hline rodzice & $\begin{array}{l}\text { środowisko } \\
\text { szkolne }\end{array}$ & 45,3990 & 100 & 9,65951 & \multirow{2}{*}{0,24846} & \multirow{2}{*}{$-13,53824$} & \multirow{2}{*}{0,00000} \\
\hline $\begin{array}{l}\text { dzieci } \\
\text { i młodzież }\end{array}$ & $\begin{array}{l}\text { środowisko } \\
\text { szkolne }\end{array}$ & 70,1100 & 100 & 18,07219 & & & \\
\hline
\end{tabular}

n - liczba obserwacji, SD - odchylenie standardowe,

$\mathbf{p}$ - poziom istotności statystycznej, $\mathbf{t}$ - wynik testu t studenta

Z powyższych danych wynika, że zanim rozpoczęła się pandemia COVID-19 jakość życia dzieci i młodzieży w rozumieniu zdrowia fizycznego była na wysokim poziomie zarówno w grupie rodziców (średnia $64,7)$ jaki i dzieci $(63,65)$. Samopoczucie psychiczne, niezależność i relacje z rodzicami obu grupach było na bardzo wyrównanym poziomie. Jedynie wsparcie społeczne oraz środowisko szkolne rodzice oceniali na niższym poziomie w stosunku do swoich pociech. 


\section{Analiza statystyczna}

Analiza statystyczna nie wykazała istotnej zależności pomiędzy oceną zdrowia fizycznego, samopoczucia psychicznego, niezależności i relacji z rodzicami przez rodziców a oceną przez dzieci i młodzież.

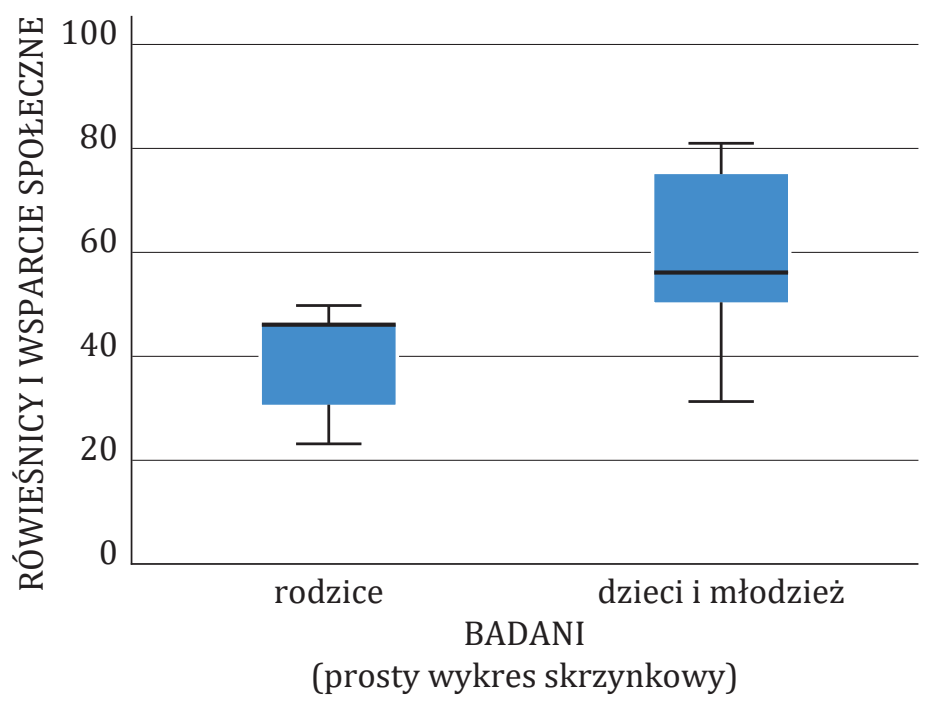

Ryc. 1. Wsparcie społeczne

Analiza statystyczna wykazała istotną zależność pomiędzy oceną rówieśników i wsparcia społecznego przez rodziców a oceną przez dzieci i młodzież. Dzieci oraz młodzież zdecydowanie wyżej oceniają wsparcie społeczne i rówieśników. 


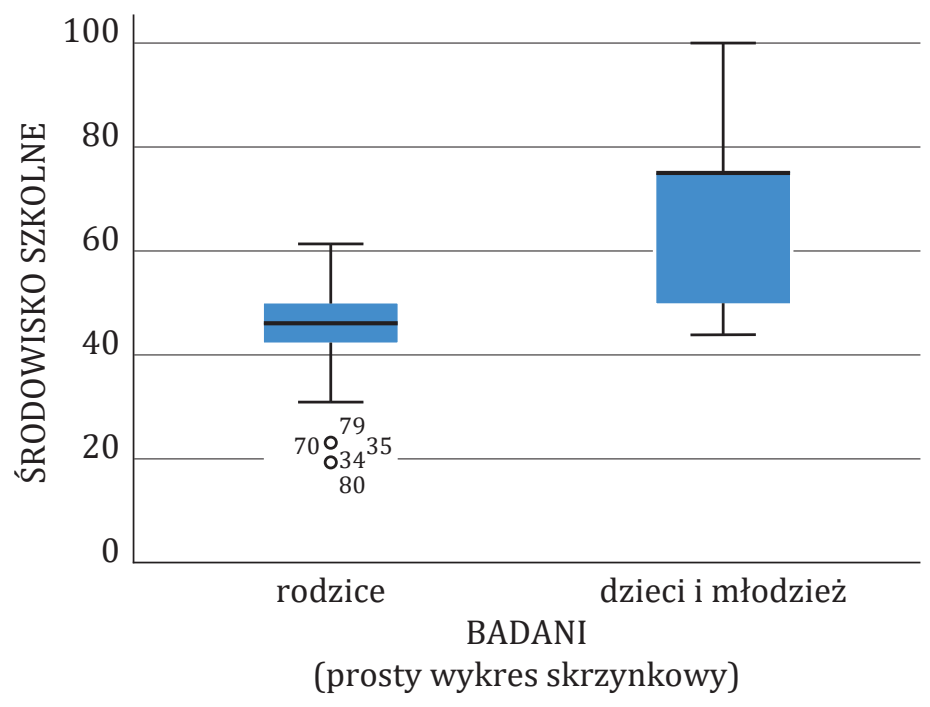

Ryc. 2. Środowisko szkolne.

Analiza statystyczna wykazała istotną zależność pomiędzy oceną środowiska szkolnego przez rodziców a oceną przez dzieci i młodzież. Dzieci oraz młodzież zdecydowanie wyżej oceniają środowisko szkolne.

Analiza statystyczna nie wykazała istotnej zależności pomiędzy płcią i pochodzeniem rodziców a ich opinią czy obecnie panująca pandemia COVID-19 ma wpływ na relacje w rodzinie. 
Tabela 4. Wpływ pandemii COVID-19 na relacje rodzinne $\mathrm{w}$ grupie rodziców - w odniesieniu do wykształcenia.

\begin{tabular}{|c|c|c|c|c|c|c|c|c|}
\hline \multirow{2}{*}{\multicolumn{3}{|c|}{ Rodzice }} & \multicolumn{3}{|c|}{$\begin{array}{l}\text { 14. Czy według Pana/Pani } \\
\text { obecnie panująca pande- } \\
\text { mia CoVID-19 ma wpływ } \\
\text { na relacje w rodzinie? }\end{array}$} & \multirow{2}{*}{$\frac{\Xi}{0}$} & \multirow[t]{2}{*}{$\chi^{2}$} & \multirow[t]{2}{*}{$\mathbf{p}$} \\
\hline & & & Tak & Nie & $\begin{array}{c}\text { Nie } \\
\text { wiem }\end{array}$ & & & \\
\hline \multirow{8}{*}{ 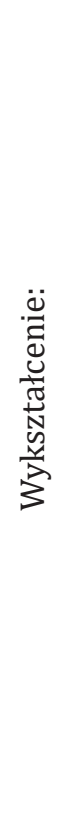 } & $\stackrel{\mathbb{N}}{\mathrm{N}}$ & $\mathrm{n}$ & 24 & 1 & 1 & 26 & \multirow{10}{*}{25,45} & \multirow{10}{*}{0,0001} \\
\hline & $\xi$ & $\%$ & $92,3 \%$ & $3,8 \%$ & $3,8 \%$ & $100,0 \%$ & & \\
\hline &. & $\mathrm{n}$ & 46 & 3 & 2 & 51 & & \\
\hline & $\bar{\omega}$ & $\%$ & $90,2 \%$ & $5,9 \%$ & $3,9 \%$ & $100,0 \%$ & & \\
\hline & 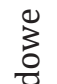 & $\mathrm{n}$ & 20 & 2 & 0 & 22 & & \\
\hline & $\begin{array}{l}3 \\
\mathbb{N} \\
N\end{array}$ & $\%$ & $90,9 \%$ & $9,1 \%$ & $0,0 \%$ & $100,0 \%$ & & \\
\hline & $\begin{array}{l}0 \\
3 \\
0 \\
3\end{array}$ & $\mathrm{n}$ & 0 & 0 & 1 & 1 & & \\
\hline & $\begin{array}{l}0 \\
8 \\
0\end{array}$ & $\%$ & $0,0 \%$ & $0,0 \%$ & $100,0 \%$ & $100,0 \%$ & & \\
\hline \multirow{2}{*}{\multicolumn{2}{|c|}{ Ogółem }} & $\mathrm{n}$ & 90 & 6 & 4 & 100 & & \\
\hline & & $\%$ & $90,0 \%$ & $6,0 \%$ & $4,0 \%$ & $100,0 \%$ & & \\
\hline
\end{tabular}

$\mathbf{n}$ - liczba obserwacji, p - poziom istotności statystycznej, $\chi^{2}-$ wynik testu chi kwadrat Persona

Analiza statystyczna wykazała istotną zależność pomiędzy wykształceniem rodziców a ich opinią czy obecnie panująca pandemia COVID-19 ma wpływ na relacje w rodzinie. Ponad $92 \%$ badanych z wykształceniem wyższym przyznaje iż obecnie panująca pandemia COVID-19 ma wpływ 
na relacje w rodzinie. Natomiast ponad $9 \%$ badanych z wykształceniem zawodowym jest odmiennego zdania i uważa że obecnie panująca pandemia nie ma wpływu na relacje $w$ rodzinie.

Tabela 5. Wpływ pandemii COVID-19 na relacje rodzinne w grupie rodziców - w odniesieniu do wieku ankietowanych.

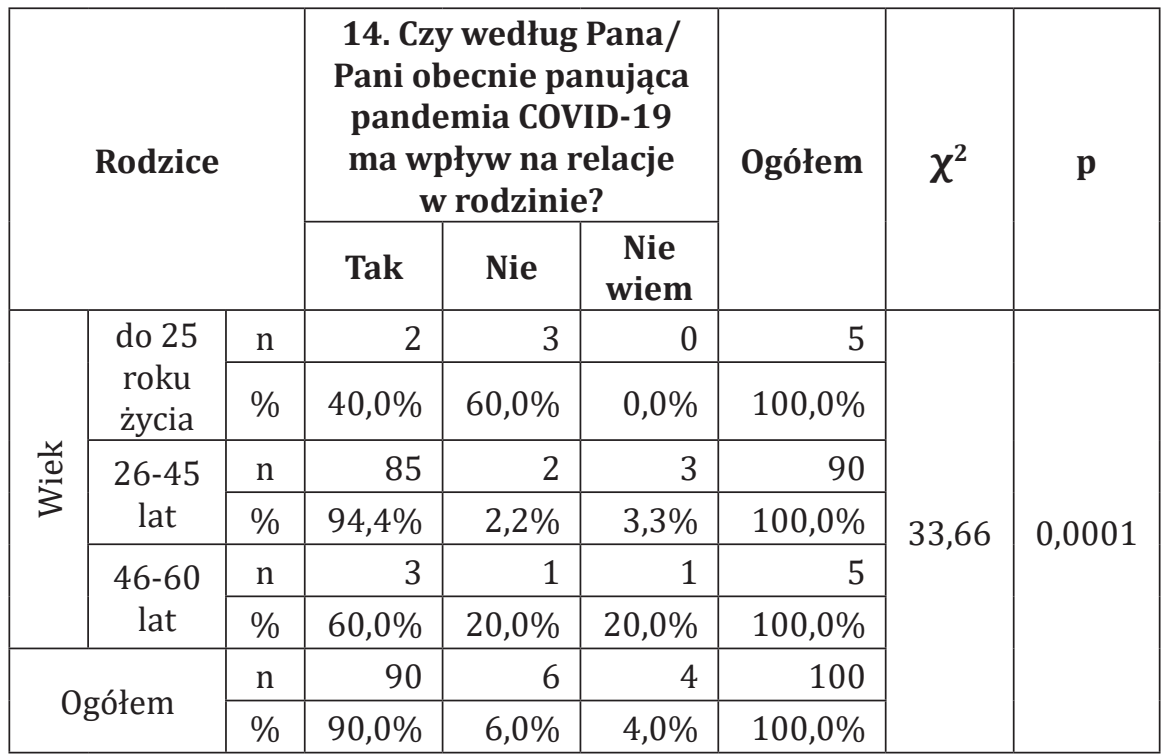

n - liczba obserwacji, p - poziom istotności statystycznej, $\chi^{2}$ - wynik testu chi kwadrat Persona

Analiza statystyczna wykazała istotną zależność pomiędzy wiekiem rodziców a ich opinią czy obecnie panująca pandemia COVID-19 ma wpływ na relacje w rodzinie. Ponad 94\% badanych w wieku 26-45 lat przyznaje iż obecnie panująca pandemia COVID-19 ma wpływ na relacje w rodzinie. Natomiast $60 \%$ badanych do 25 roku życia jest odmiennego zdania i uważa że obecnie panująca pandemia COVID-19 nie ma wpływu na relacje $w$ rodzinie.

Analiza statystyczna nie wykazała istotnej zależności pomiędzy wiekiem, płcią i pochodzeniem dzieci i młodzieży a ich opinią czy obecnie panująca pandemia COVID-19 ma wpływ na relacje w rodzinie. 


\section{Dyskusja}

Rok 2020 przyniósł każdej rodzinie w Polsce, ale też na całym świecie nieoczekiwany zwrot w codziennym funkcjonowaniu. Ta niezwykła, często trudna rzeczywistość trwa do dnia dzisiejszego i pomimo buntu jest naszą codziennością. Nowa sytuacja zaburzyła spokój, który otaczał każdą rodzinę. Pandemia COVID-19 dotknęła każdy aspekt życia i wiązała się nie tylko ze stanem zdrowia, ale również z procesami gospodarczymi, zawodowymi, organizacją pracy, edukacji, nawyków, zwyczajów kulturowych. W takiej sytuacji relacje międzyludzkie, które warunkowały harmonię codziennego życia w istotny sposób nabrały większego znaczenia. Pandemia przyczyniła się z czasem do znaczącego pogorszenia tych relacji.

Bez wątpienia częste przebywanie wszystkich członków rodziny $\mathrm{w}$ jednym miejscu, zamkniętych $\mathrm{w}$ domach, stosunkowo może przyczynić się do pogłębienia bliskości i zacieśnienia relacji. Nierzadko dochodzi jednak do sytuacji konfliktowych, zwłaszcza w przypadku zmęczenia, stresu, frustracji spowodowanej nie tylko pandemią, ale także zwiększoną ilością obowiązków [4].

Założono, iż funkcjonowanie rodziny i dziecka w dobie pandemii wpływa negatywnie na aspekt zdrowia fizycznego całej rodziny. Wysiłek fizyczny to ruch ciała bądź skurcz mięśni szkieletowych prowadzący do wzrostu wydatków energetycznych organizmu. Ciało człowieka zostało „zaprogramowane” do ruchu, dlatego potrzebuje regularnego wysiłku fizycznego do prawidłowego funkcjonowania, a tym samym unikania chorób [5, 6]. Zdrowie jest pierwszorzędną wartością i każdy człowiek powinien o nie dbać. Jego stan determinuje jakość życia zarówno w ujęciu medycznym jak i społecznym. Dotyczy sfer życia takich, jak: stan fizyczny oraz sprawność ruchowa, kondycja psychiczna, sytuacja społeczna. Aktualnie istnieje szereg dowodów ukazujący, że osoby prowadzące fizycznie aktywny tryb życia osiągają korzyści zdrowotne. Wysiłek fizyczny ma wpływ na wiele układów organizmu człowieka (krwionośny, mięśniowy, oddechowy oraz kostno-stawowy) oraz na stan psychiczny [7]. 
Ankietowani rodzice to w większości mieszkańcy wsi - 62\%, oraz osoby z wykształceniem średnim ogólnokształcącym 52\%. Odpowiadając na pytania dotyczące szeroko pojętej aktywności fizycznej zarówno rodzice, jaki i dzieci uważały, że przed zastosowaniem obostrzeń ich aktywność fizyczna była na wysokim poziomie - dla dorosłych $64,7 \%$, a dla dzieci $63,6 \%$.

Aktywność fizyczna dziecka w czasie pandemii jest bardzo ograniczona. Dzieci uczęszczają do szkoły sporadycznie, zależnie od wyników zakażeń. Ciągłe przebywanie w domu, w trakcie zdalnego nauczania może przyczynić się do pojawienia otyłości, zaniedbania diety, pogorszenia wzroku, boli mięśniowych w okolicy szyi i karku itp. Sposób spędzania czasu wolnego przez dziecko wpływa niejako na sposób w jaki spędza swój czas wolny rodzina. Ankietowani rodzice wskazując na to, iż dzieci w czasach sprzed pandemii były bardziej aktywne i pełne życia. Analiza ankiet KIDSCREEN 27 ukazuje, że zarówno w grupie rodziców jak i dzieci ponad 60\% respondentów deklaruje, że czas przed pandemią spędzali bardzo aktywnie, a ich samopoczucie było bardzo dobre (73\% dzieci). Teraz w związku z licznymi zakazami, sposoby na wszelkie aktywności zwłaszcza na świeżym powietrzu są bardzo ograniczone.

Druga kwestia wiąże się z sytuacją koniecznej hospitalizacji dziecka w dobie znacznych ograniczeń, co negatywnie wpływa na zdrowie psychiczne całej rodziny. Jak podaje Perek i Cepuch pacjent w wieku rozwojowym różni się od dorosłego chorego i wymaga swoistych warunków leczenia i hospitalizacji. Dziecko ze względu na niedojrzałą psychikę, czułą i podatną na urazy nie potrafi radzić sobie w nowych trudnych sytuacjach i stosować skutecznych strategii przystosowawczych. Bywa często niesamodzielne, bezbronne, uzależnione od osób dorosłych. Szpital w przeciwieństwie od naturalnego środowiska domowego jest dla dziecka środowiskiem sztucznym, nowym i obcym. Pozbawia je często stałej obecności matki i bliskich osób gwarantujących poczucie bezpieczeństwa, ogranicza możliwość zaspokojenia wielu potrzeb rozwojowych i prowadzenia typowej dla wieku codziennej 
aktywności. Będące w okresie intensywnego rozwoju psychofizycznego dziecko potrzebuje zaspokojenia podstawowych potrzeb psychicznych, jak: więzi emocjonalnej z matką, miłości, poczucia bezpieczeństwa, aktywności poznawczej i ruchowej, zabawy, nauki. Przebywanie w szpitalu, oddzielenie od rodziców i rodzeństwa naraża małego pacjenta na deprywację fundamentalnych potrzeb, naruszając jego sferę emocjonalną [8]. Z powodu zmiany otoczenia oraz rozłąki z matką następuje deprywacja bardzo ważnych potrzeb determinujących rozwój - bezpieczeństwa, bliskości i kontaktu emocjonalnego. Unieruchomienie i konieczność pozostania w łóżku zakłóca potrzebę ruchu i aktywności, którą szczególnie silnie odczuwają młodsze dzieci. Ograniczenie samodzielności i długotrwała zależność od osób sprawujących opiekę powoduje, że dzieci stają się bierne, nastawione roszczeniowo, opóźnieniu ulega proces usamodzielniania się dziecka oraz kształtowania się jego woli i motywacji [9].

Analizując wyniki, aż 78\% rodziców uważa, że ich dzieci hospitalizowane są samotne i brakuje im kontaktu z pozostałymi członkami rodziny czy też przyjaciółmi, dzieci (88\%) potwierdzają te odczucia. Ponadto dorośli ankietowani (84\%) stwierdzają, że ich pociechy tęsknią za domem, badani z grupy dziecięcej (91\%) również uznają, że są stęsknieni za domem rodzinnym. Pomimo, że dzieci uważają, że czują się bezpiecznie w szpitalu (45\%), zapewne ma to związek z wiekiem respondentów - $49 \%$ ankietowanych było wieku od 12 do 18 lat. Dla nastolatka jest to czas dużej samodzielności, jednak każda hospitalizacja bywa trudnym doświadczeniem. W czasie pandemii sytuacja ta jest niebywale ciężka z uwagi na fakt ilości ograniczeń oraz restrykcji wobec rodziców i dziecka.

Kolejny problem dotyczy zaburzonych relacji społecznych wśród rodzin dzieci hospitalizowanych $w$ czasie pandemii. $Z$ danych przeprowadzonych w oddziale wynika, że $77 \%$ ankietowanych rodziców odczuwa niepokój związany z pobytem dziecka w szpitalu. Strach o zdrowie dziecka determinuje wszystkie aspekty życia rodzinnego, jaki i zawodowego. Rodzice pozostający z dziećmi w szpitalu (83\% ankietowanych) 
często zmuszeni są skorzystać ze zwolnień lekarskich, bądź też wykorzystywać urlopy wypoczynkowe - zdarzają się epizody problemów w pracy związanych z nieobecnością. Nierzadko przebywając z jednym dzieckiem w oddziale zostawiają kolejne dziecko w domu. Rodzice są przemęczeni, zdenerwowani, niespokojni.

Jak podaje Jakubik kluczową rolę we wsparciu rodzica w hospitalizacji dziecka odgrywa pielęgniarka, gdyż jest odpowiedzialna za proces pielęgnowania [10].

Badani rodzice podają, że poznali zasady panujące w oddziale $86 \%$ oraz otrzymują dostateczne informacje na temat zdrowia swoich dzieci 71\%. Jednakowoż sytuacja w szpitalu związana z licznymi ograniczeniami funkcjonowania w oddziale w czasie pandemii nie ułatwia skupienia się na wspieraniu dziecka w trudnym procesie leczenia. Ponad 90\% ankietowanych dorosłych uważa, że pandemia wpływa na relacje w rodzinie, potwierdzają to także wyniki u dzieci (88\%).

Ostatnia rozważana kwestia odnosi się do negatywnego wpływu hospitalizacji na jakość życia rodziny w dobie pandemii. Idea jakości życia odnosząca się do medycyny jest specyficzna, gdyż obiektywny stan zdrowia nie wyznacza ostatecznie zaspokojenia potrzeb a także poczucia szczęścia. Czasem bywa, że osoby schorowane mogą mieć inne odczucia wyrażające jakość życia, niż osoby, które mogą funkcjonować bez przeszkód w aspekcie fizycznym i społecznym. Występuję różne reakcje na chorobę czy trudne sytuacje wywołujące stres. Na postrzeganie sytuacji choroby przez pacjenta jak również jego rodzinę składa się nie tylko ocena objawów schorzenia, ale również sposoby radzenia sobie z skutkami choroby, ocena możliwości normalnego funkcjonowania a także odnajdowanie metod wspomagających utrzymania kontroli nad chorobą. Ogromne znaczenie ma osobowość pacjenta, wiek, wykształcenie, status ekonomiczny i społeczny oraz wpływy kulturowe [11].

W wynikach badań ankiet KIDSCREEN 27 w grupie rodziców, aż $73 \%$ respondentów podało, że ich dzieci w czasie przed pandemią rzadko były smutne, potwierdzają to także wyniki w grupie dzieci - 59\%. Ponadto na podstawie wyników kwestionariusza KIDSCREEN 27 dzieci 
i młodzież odnosząc się do czasów sprzed rozpoczęcia pandemii COVID-19 wysoko oceniają niezależność i relacje z rodzicami $(60,65 \%)$, najniżej natomiast samopoczucie psychiczne $(51,11 \%)$. Pandemia wywarła ogromny wpływ na organizację życia, a w omawianych badaniach mamy do czynienia z pacjentem pediatrycznym oraz jego nierzadko zestresowanym rodzicem, dlatego jak wspomniano powyżej 77\% dorosłych odczuwa niepokój związany z chorobą dziecka i jego często rychłą hospitalizacją. Niespodziewane sytuacje takie, jak choroba bliskiej osoby determinują spokojną dotąd egzystencję, zwłaszcza w czasie pandemii. Jak wynika z przeprowadzonych badań, aż 83\% ankietowanych rodziców obawia się zakażenia COVID-19.

\section{Wnioski}

1. Pandemia wirusa COVID-19 odcisnęła ogromne piętno w funkcjonowaniu rodziny. $\mathrm{W}$ aspekcie fizycznym $\mathrm{w}$ wyniku zastosowanych obostrzeń dorosłym i dzieciom brakuje wszelkich aktywności. Dzieci i młodzież kiedyś czynnie korzystający z różnorakich form aktywności (średnio 63,65\% ankietowanych dzieci) zmuszona jest przebywać w warunkach domowych i ograniczać swoje pasje do minimum.

2. Konieczność hospitalizacji dziecka ma znaczny wpływ na jego psychikę. Dzieci pomimo towarzystwa przybywającego z nim w szpitalu rodzica odczuwają wachlarz emocji, od strachu po samotność (88\%) i tęsknotę za środowiskiem domowym oraz przyjaciółmi (91\%).

3. Pobyt dziecka w szpitalu zaburza relacje w rodzinie. Dorośli skupieni na procesie leczenia swoich pociech, nierzadko zaniedbują życie rodzinne, jak i zawodowe. Stres o zdrowie dziecka (77\%) weryfikuje wypracowane dotąd schematy i relacje rodzinne.

4. Jakość życia w rodzinie w dobie pandemii nabiera całkiem innego wymiaru. W wyniku restrykcji konieczne jest przeorganizowane życia w każdej sferze. Podobnie sytuacja wygląda w szpitalu. Wcześniejszy regulamin odwiedzin, czy jak w przypadku 
pacjentów pediatrycznych możliwość pobytu rodzica całą dobę w szpitalu, zostały mocno okrojone. Obecnie tylko jeden rodzic ma prawo być przy dziecku. Wiążę się z tym brak możliwości wymiany rodziców, nasila się stres związany z chorobą dziecka (77\% respondentów odczuwa niepokój związany z hospitalizacją dziecka) oraz tęsknotą za pozostałymi członkami rodziny. Choroba dziecka jest zawsze źródłem stresu i lęku, jednak w dobie pandemii owy stres nabiera podwójnego znaczenia, gdyż rodzice oprócz strachu o życie dziecka obawiają się zakażenia wirusem i tym samym martwią się o własne zdrowie (83\% dorosłych ankietowanych).

\section{Zalecenia dla praktyki pielęgniarskiej}

Czas pandemii, będący wyzwaniem dla wszystkich, będzie skutkował wieloma konsekwencjami i wyzwaniami dla systemu opieki zdrowotnej. Priorytetowymi obszarami działań powinno być wspieranie dzieci i ich rodzin w zapobieganiu lub niwelowaniu zaburzeń wynikających nie tylko z sytuacji choroby dziecka, ale również z sytuacji epidemiologicznej.

\section{Bibliografia/Bibliography:}

1. Krawczyk E. Koronawirus. Wszystko co musisz wiedzieć, żeby się zabezpieczyć, Wyd. Pascal, 2020.

2. Krzystyniak K. Koronawirus. COVID-19 \MERS \SARS. Epidemiologia/ leczenie/ profilaktyka, Wyd. Medyk, 2020:24-30.

3. Heitzman J. Wpływ pandemii COVID-19 na zdrowie psychiczne, Psychiatr. Pol. 2020;54(2):187-198.

4. Heszen I., Sęk H. Psychologia zdrowia. PWN, Warszawa 2008.

5. Birch K., MacLaren D., George K. Krótkie wykłady. Fizjologia sportu. Wyd. Naukowe PWN, Warszawa 2012. 
6. Wojtasik W., Szulc A., Kołodziejczyk M., Szulc A. Selected issues concerning the impact of physical exercise on the human organism. Journal of Education, Health and Sport, 2015;5(10):350-372.

7. Idzik A., Idzik M., Majewski J. Zdrowie i jakość życia mieszkańców Polski w ujęciu regionalnym. Sport i rekreacja a wyzwania współczesnej cywilizacji, 2011;37(1):497-509.

8. Perek M., Cepuch G. Dziecko w szpitalu a ryzyko krzywdzenia instytucjonalnego, Studia Medyczne 2008;11:23-27.

9. Maruszczak M. Doświadczenie hospitalizacji. Encyklopedia Rodzice i Dzieci. Wydawnictwo Park, Bielsko-Biała 2002.

10. Jakubik M., Kierys A., Bednarek A. Udział pielęgniarki w adaptacji dziecka do warunków szpitalnych. Problemy Pielęgniarstwa 2011;19(4):545550.

11. Wnuk M., Marcinkowski J. Jakość życia jako pojęcie pluralistyczne o charakterze interdyscyplinarnym. Problemy Higieny i Epidemiologii, 2012;93:21-26. 